International Journal of Psychological Research and Reviews
(ISSN:2639-6041)

\title{
Transtorno Obsessivo Compulsivo
}

\section{Dennys Lapenda Fagundes}

Psychiatric and Sleep Doctor. Master in Neuropsychiatry in Federal University of Pernambuco. CBT Specialist

\section{ABSTRACT}

Obsessive Compulsive Disorder (OCD) is a disease that affects many psychopathological segments with the predominance of obsessive ideas or uncontrollable behaviors. Obsessions are *Correspondence to Author: Dennys Lapenda Fagundes presented as intrusive thoughts that cause increased anxiety; Psychiatric and Sleep Doctor. Maswhile compulsions present themselves as repetitive behaviors or ter in Neuropsychiatry in Federal mental acts aimed at minimizing anxiety. OCD was considered a very rare and poor prognosis, but with advances in scientific research, this concept is in the process of changing.

How to cite this article:

Dennys Lapenda Fagundes. Transtorno Obsessivo Compulsivo. International Journal of Psychological Research and Reviews, 2020; 3:41.

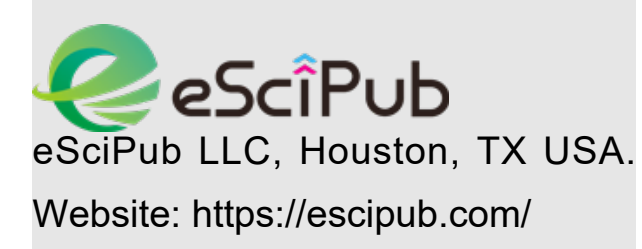




\section{INTRODUCTION}

OCD was referred to as "Madness of Doubt", "Delirium Without Delirium", "Lucid Madness", which can possibly be attributed to the higher number of non-OCD diagnoses performed, besides reflecting some of its characteristics such as pathological doubt and the usual preservation of criticism. OCD is the tenth leading cause of disability in the world according to $\mathrm{WHO}$ and the fourth most common psychiatric disorder. Some authors believe that the prevalence of OCD is 1 to $10 \%$, including outpatients and hospitalized patients. Emotional discomfort in OCD assumes multiple manifestations, including anxiety and fear, doubt, disgust, guilt, feeling of imperfection or incompleteness. Onset usually begins in childhood and symptoms change with time course. In Brazil, it is estimated that 5 million people suffer from $O C D$, with an equal sex ratio (1/1), with males aged around 6 to 15 years and females around 20 to 29 years.

In ICD-10, OCD falls under code F42, where F42.0 is OCD with predominance of obsessive ideas or ruminations, F42.1 is OCD with predominance of compulsive behaviors (obsessive rituals), F42.2 is OCD mixed form, with obsessive ideas and compulsive behaviors, F42.8 other TOCs and F42.9 is unspecified OCD. In DSM V, OCD is allocated to the isolated category (where there is a genetic association between disorders), in DSM IV it was part of anxiety disorders: OBSESSIVE COMPULSIVE AND RELATED DISORDER 1. Body Dysmorphic Disorder 2. Accumulation Disorder 3. Trichotillomania 4. Neurotic excoriation (skin picking) 5. Substance / medication induced OCD 6. OCD related to another medical condition 7. OCD not specified (eg pathological jealousy)

\section{ETIOLOGY}

The dominant etiological hypothesis states that numerous genes with little effect for phenotypic variation interact with multiple environmental factors, and no single gene susceptible to OCD has been identified. The greatest evidence shows that the genes involved are from the glutamatergic system (slc1a1 on chromosome 9p24). The hereditary factor promotes a 3 to 12-fold increase in the risk of OCD in relatives of first-degree patients. In addition to the genetic issue, environmental risk factors are also highlighted as: perinatal factors (childbirth trauma, history of childhood sexual abuse, childhood-triggered streptococcal infection (Sydenham's rheumatic fever with or without chorea). The brain circuits of patients with OCD were found to function abnormally and the most affected circuit is the pale striated thalamic cortical cortex. The brain areas involved in the etiology correlate with the specific symptoms.

\section{MOTOR CIRCUIT (PUTAMEN) - SYMMETRY / ARRANGEMENT LIMBIC CIRCUIT (VENTRAL STRIED) WASHING PRE - FRONT CIRCUIT (NUCLEO CAUDADO) CHECKING AND COLLECTIONISM}

The neurological substrate of OCD showed that after pharmacological and behavioral treatment there is a reduction in metabolic activity in the brain circuits most involved. The neurotransmitter glutamate showed an association between high levels and the presence of obsessive - compulsive symptoms, which tend to normalize after selective serotonin inhibition following symptom improvement. The neuroimmunological factors of OCD, following infection with group $A$ hemolytic beta streptococcus, the same agent of rheumatic fever, promote a cross reaction with the basal ganglia of the brain. Some life events such as late pregnancy and the postpartum period are associated with the onset of OCD, including in men who have just become parents. Excessive concerns about newborn welfare and intrusive thoughts are common. In addition, recent change, marriage or sexual problems, and illness or death of close people.

\section{CLINICAL FRAMEWORK, DIAGNOSIS AND COMORBIDITIES}


OCD diagnosis is established with the presence of obsessions (thoughts, images or impulses) and / or compulsions that may or may not be observable (mental rituals such as praying or telling). It is a very heterogeneous disorder with symptoms that have a transcultural and transhistorical universality.

OBSESSIONS: Undesirable, intrusive and repetitive, generating great anxiety or emotional discomfort.

RITUALS COMPULSIVE: to Volunteers, as they temporarily alleviate discomfort and become repetitive.

Obsessive thoughts present as themes aggressiveness, disease, death, filth, contamination, sexuality, religiosity, neutrals (intrusive words, sounds or music).

\section{AGGRESSIVENESS}

Fear of situations of violence, accident or death of the patient or loved ones. These symptoms may manifest as egodistonic impulses or impulse phobias, characterized by fear of harming, injuring or killing someone or oneself. They are accompanied by recurring doubts about whether or not they have committed such acts, as well as dodging behavior in situations that might trigger such obsessions.

\section{DIRT OR CONTAMINATION}

Currently the fear of AIDS and H1N1 stand out and there may be somatic obsessions related to non-contagious diseases such as cancer or physical appearance.

\section{SEXUALS}

Inopportune and generate guilt, unlike sexual fantasies.

\section{RELIGIOUS}

Concerns about sin, blasphemy and sacrilege.

\section{CHECK OR CHECK}

They are associated with somatic (physical selfexamination) or aggressive obsessions (making sure you haven't killed someone), fear of causing a catastrophe (checking if you locked the door, turned off the iron, put out the cigarette, if food is inside shelf life).

\section{CLEANING}

They are often associated with obsessions of dirt or contamination, which can lead to severe physical wear, bathing and tooth brushing, hand washing, household items, furniture, bags, keys or documents.

\section{SCORE}

They are usually mental and are related to repetition (unnecessary sums and divisions, repeating certain acts a certain number of times).

\section{ORDINATION}

Storage of clothes on the clothesline; symmetry of clothes and shoes, Touches or bumps, reading a word of bad connotation (death) need words that nullify (life) to alleviate the worry.

\section{COLLECTION}

Need to accumulate or fear of disposing of various things, such as newspapers or invoices, useless packaging, broken or found objects on the street. In this way, the house can become a storehouse for objects that can barely be moved.

\section{OBSESSIVE PRIMARY LESSON}

Presentation of less usual OCD. Patients do not repeat their actions, but take a long time in simple tasks such as dressing or brushing their teeth, probably due to doubts, fears, perfectionism or covert rituals.

\section{JEALOUS}

In general, associated with checking rituals, patients have questions about partner fidelity or intrusive mental images of betrayal, and need to make sure they are not being betrayed. They often check to see if the person is right where they say they are; if there is evidence of betrayal in personal effects, clothing, telephones, electronic correspondence. Even knowing that the betrayal has not occurred or will not occur, the patient cannot calm down and acts insistently to resolve the doubt, often regrets and blames himself for causing suffering to the spouse. In some cases the 
criticism may be compromised. Pathological jealousy can occur in other disorders such as schizophrenia, persistent delusional disorder, major depression, alcohol abuse and dementia.

\section{SENSORY PHENOMENA (Compulsions without obsessions)}

Uncomfortable sensations, feelings, or perceptions that precede or accompany the performance of repetitive behaviors. Physical: Feeling that the hands are dirty, oily and the need to wash them. Mental: Turn the light switch on and off until you feel internally in order, fix a frame on the wall until you are visually ready.

\section{SENSORY PHENOMENA}

Such sensations were initially described in patients with Tourette's syndrome. Uncomfortable physical sensations in the skin or muscles, visual, auditory or tactile perceptions that something is not as it should or just right, a sense of unfinished or incomplete, and tension or "energy" only relieved by behavior. be present in up to $70 \%$ of cases, early onset, associated with Tics. Symptoms of symmetry, ordering, or more severe counting can present themselves in endless ways. The symptomatology changes in the patient with the evolution of the disease.

\section{CRITICAL CAPACITY}

The classic view that OCD patient criticism is preserved is no longer accepted. Clinical cases of early onset, with greater number and severity of symptoms, which are presented not as typical (egodistonic) obsessions but as overvalued or prevalent (egosyntonic) ideas. The secret character of OCD should be valued, because as criticism is preserved, in general, the patient tends to ritualize secretly, controlling and hiding the obsessive compulsive symptoms of family members as much as possible.

\section{COGNITIVE ASPECTS}

There are 6 main domains of dysfunctional beliefs:

\section{Exaggerated Personal Responsibility}

2. Risk overestimation

3. Overvaluation of thoughts

4. Excessive worry about controlling thoughts

5. Intolerance to uncertainty

6. Perfectionism

\section{COGNITIVE ASPECTS}

Many patients fear to feel guilty about some catastrophic event that may happen to others and ritualize to try to prevent them. Others have an exaggerated assessment of the dangers, feeling extremely threatened (fear of contamination or death). Protective behaviors temporarily alleviate both types of fears. Intrusive thoughts are universal, but such individuals find them unacceptable. Thoughts become overriding and lead to emotional discomfort and the need for safety-assurance behaviors, which ultimately reinforce the vicious cycle. This magical and bizarre nature of TOC is a motive that puts it in a special category at DSM V.

\section{SUBTIPOSES}

The subtypes that are most present in the studies are tic-associated OCD, with early onset of symptoms and toc related to streptococcal infection. The worst response to OCD treatment is associated with early onset rheumatic fever. CLINICAL COURSE In children there is a predominance in boys and in adolescence there is a predominance among girls. Collecting, aggression obsessions, and worse criticism are more child-related, as opposed to sexual obsessions that are more adult-related. They present chronic course with episode of improvement or worsening.

\section{DSM V CRITERIA}

Obsessions or compulsions with the recognition that obsessive compulsive symptoms are excessive or meaningless consume more than 1 hour a day. They cause suffering or social, occupational or other important areas of functioning. OCD related to tics is around thirty percent. Motor tics are the most common. It has been found that there is a common genetic 
inheritance. The patient presenting tic has a high chance of presenting OCD. Comorbidities Ninety percent of patients have some associated mental disorder. Mood disorder (major depression), anxiety disorder (tag and social phobia), tics and often separation anxiety is the first symptom of toc.

\section{TREATMENT TREATMENT OCD}

PHARMACOLOGICAL

Treatment can be established based on psychotherapeutic, pharmacological and interventionist interventions, the initial two being the main alternatives. At the beginning of the clinical follow-up, it is important to carry out a careful evaluation of the patient to choose the best form of treatment. The pharmacological possibilities for OCD patients that demonstrate greater scientific evidence, with the average doses to be achieved during treatment, are shown in the table below:

CLOMIPRAMINE 300 MG / DAY (GOLD STANDARD) FLUVOXAMINE 300 MG / DAY PAROXETINE 60 MG / DAY SERTRALINE 250 MG / DAY FLUOXETIN 80 MG / DAY CITALOPRAM 60 MG / DAY ESCITALOPRAM $40 \mathrm{MG} / \mathrm{DAY}$

\section{PSYCHOTHERAPY}

Together with the pharmacological treatment line, psychotherapy, in particular behavioral therapy, emerges in a prominent role with techniques, especially exposure and response prevention. These techniques have also been recognized as first-line alternatives and should be suggested in partnership with medications. It acts in the alteration of the classical coding as the operant, being a challenge for the psychotherapist to stimulate its patients the adhesion of the technique.

NEUROBIOLOGICAL INTERVENTIONAL ELECTROCONVULSTERAPY
Although ECT is not effective for OCD in the literature, we found some case reports reporting improvement with intervention.

\section{NEUROSURGERY}

Therapeutic efficacy indices after neurosurgical interventions are not very reliable. Capsulotomy has 56 to $100 \%$, cingulotomy 27 to $57 \%$, subcaudate tratotomy 33 to $67 \%$ and limbic leukotomy 61 to $69 \%$. Because these techniques are invasive and irreversible, they can have unwanted side effects such as seizures, delirium, hemorrhages and infections.

\section{REFERENCES}

1. Berrios GE. Historia de los trastornos obsesivos. In: Ruiloba JV, Berrios GE editores. 2. ed. Estados obsesivos. Barcelona: Masson; 1995. p. 1-14.

2. American Psychiatry Association. Diagnostic and Statistical Manual for Psychiatry Disorders: DSM-V. 5th ed. Washington: APA; 2013.

3. Weissmann MM, Bland RC, Canino GJ, Greenwald S, Hwu HG, Lee CK, et al. The cross national epidemiology of obsessive compulsive disorder: the cross national collaborative group. $\mathrm{J}$ Clin Psychiatry. 1994;55(3):5-10.

4. Miguel EC, Ferrão YA, Rosário MC, Mathis MA, Torres AL, Fontenelle LF, et al. The Brazilian Research Consortium on Obsessive-Compulsive Disorders: recruitment, assessment instruments, methods for the development of multicenter collaborative studies and preliminary results. Rev Bras Psiq. 2008;30(3):185-96.

5. Almeida Filho N, Mari JJ, Coutinho E, França JF, Fernandes JF, Andreoli SB, et al. Estudo multicêntrico de morbidade psiquiátrica em áreas urbanas brasileiras (Brasília, São Paulo, Porto Alegre). Revista ABP-APAL. 1992;14(3):93-104.

6. Organização Mundial da Saúde. Classificação Estatís- tica Internacional de Doenças e problemas relacionados à saúde: CID-10. 10. ed. São Paulo: USP; 2007.

7. De Hann E, van Oppen P, van Balkom AJLM, Spinhoven P, Hoogduin KAL, Van Dyck R, et al. Prediction of outcome and early vs. Late improvement in OCD patients treated

1. with cognitive behaviour therapy and pharmacotherapy. Acta Psychiatr Scand. 1997;96(5):354-61.

8. Refractory. Encyclopaedia Britannica Company. 
Merriam-Webster. 2014 [capturado em 01 ago. 2014]. Disponível em: http://www.merriamwebster.com/ dictionary/refractory.

9. Resistant. Encyclopaedia Britannica Company. Merriam-Webster. 2014 [capturado em 01 ago. 2014]. Disponível em: http://www.merriamwebster.com/ dictionary/resistant.

10. Turón VJ, Salgado P. Estrategias terapéuticas en el trastorno obsesivo-compulsivo refractario. In: Ruiloba JV, Berrios GE, editores. Estados Obsesivos. 2. ed. Barce- Iona: Masson; 1995. p. 397-416.

11. Rauch SL, Jenike MA. Management of treatment resistant obsessive compulsive disorder: concepts and strategies. In: Textbook from the proceedings of the 1st IOCDC. Capri: [s.n.]; 1993. p. 12-13.

12. Schindler KM, Pato MT. Clomipramine. In: Current Treatments of Obsessive-compulsive disorder. Washing- ton: APA; 2001. p. 19-37.

13. Cordioli AV. Cognitive-behavioral therapy in obsessive-compulsive disorder. Rev Bras Psiquiatr. 2008;30(suppl.2):s65-s72.

14. Pallanti S, Hollander E, Bienstock C, Koran L, Leckman J, Marazziti D, et al. International Treatment Refractory OCD ConsortiumTreatment non-response in OCD: methodological issues and operational definitions. Int J Neuropsychopharmacol. 2002;5(2):181-91.

15. Goodman WK, McDougle CJ, Barr LC, Aronson SC, Price LH. Biological approaches to treatment-resistant Obsessive-Compulsive Disorder. J Clin Psychiatry. 1993; 54(6 suppl):1626.

16. DeVaugh-Geiss J, Katz R, Landau P, Goodman $\mathrm{W}$, Rasmussen $\mathrm{S}$. Clinical predictors of treatment response in obsessive compulsive disorder: exploratory analyses from multicenter trials of clomipramine. Psychopharm bull. 1990;26(1):549.

17. Moreno AC, Calo JJP, Pinero MV, zaragoza CL, Navarro VF Marsa MD. Evolución y respuesta terapéutica en el Transtorno ObsesivoCompulsivo. Actas Luso esp Neurol Psiquiatr Cienc Afines. 1995;23(1):9-19.

18. Ferrão YA, Shavitt RG, Bedin NR, de Mathis ME, Lopes AC, Fontenelle LF, et al. Clinical features associated to refractory obsessivecompulsive disorder. J Affect Disord. 2006;94(1-3):199-209.

19. Dougherty DD, Baer L, Cosgrove GR, Cassem $\mathrm{EH}$, Price $\mathrm{BH}$, Nierenberg AA, et al. Prospective Long-Term Follow- Up of 44 Patients Who
Received Cingulotomy for Treatment-Refractory Obsessive-Compulsive Disorder. Am J Psychiatry. 2002;159(2):269-75.

20. Murray CL, Lopez AD. The global burrion of diseases: a comprehensive assesment of mortality and disability from diseases. Cambridge: Harvard University Press; 1996.

21. Greenberg WM, Benedict MM, Doerfer J, Perrin M, Panek L, Cleveland WL, et al. Adjunctive glycine in the treatment of obsessive-compulsive disorder in adults. J Psychiatr Res. 2009;43(6):664-70.

22. Torres AR, Ramos-Cerqueira ATA, Ferrão YA, Fontenelle LF, Rosário MC, Miguel EC. Suicidality in obsessive-compulsive disorder: prevalence and relation to symptom dimensions and comorbid conditions. J Clin Psych. 2011;72(1):17-26.

23. Ferrão YA, Florão MS. Acomodação familiar e criticismo percebido em pacientes com transtorno ob- sessivo-compulsivo. J Bras Psiquiatr. 2010;59(1): 34-43.

24. Foa EB. Cognitive behavioral therapy of obsessive- compulsive disorder. Dialogues Clin Neurosci. 2010;12(2):199-207.

25. Ferrão $Y A$, Diniz JB, Lopes $A C$, Shavitt RG, Greenberg B, Miguel E. Resistance and refractoriness in obsessive- compulsive disorder. Rev Bras Psiquiatr. 2007;29(Suppl 2):S66-76.

26. Pampaloni I, Sivakumaran T, Hawley CJ, Al Allaq A, Farrow J, Nelson S, et al. High-dose selective serotonin reuptake inhibitors in OCD: A systematic retrospective case. J Psychopharmacol. 2010;24(10):1439-45.

27. The British Psychological Society, The Royal College of Psychiatrists. Obsessive-compulsive disorder: core interventions in the treatment of obsessive-compulsive disorder and body dysmorphic disorder. National Collaborating Centre for Mental Health. London: British Psychological Society, Royal College of Psychiatrists; 2006.

28. Bloch $\mathrm{MH}$, Landeros-Weisenberger A, Kelmendi B, Coric V, Bracken MB, Leckman JF. A systematic review: antipsychotic augmentation with treatment refractory obsessive-compulsive disorder. Mol Psychiatry. 2006;11(7):622-32.

29. Hollander E, Bienstock CA, Koran LM, Pallanti S, Marazziti D, Rasmussen SA, et al. Refractory Obsessive- compulsive disorder: state-of-art treatment. J Clin Psychiatry. 2002;63(6 suppl):20-9.

30. Decloedt E, Stein DJ. Current trends in drug 
Treatment of obsessive-compulsive disorder. Neuropsychiatr Dis Treat. 2010;6:233-42.

31. Diniz JB, Shavitt RG, Fossaluza V, Koran L, Pereira CA, Miguel EC. A double-blind, randomized, controlled trial of fluoxetine plus quetiapine or clomipramine versus fluoxetine plus placebo for obsessive-compulsive disorder. J Clin Psychopharmacol. 2011;31(6):763-8.

32. Koran LM, Aboujaoude E, Bullock KD, Franz B; Gamel N, Elliott M. Double-blind treatment with oral morphine in treatment-resistant obsessivecompulsive disorder. J Clin Psychiatry. 2005;66(3):353-9.

33. Zdanys K, Tampi RR. A systematic review of offlabel uses of memantine for psychiatric disorders. Prog Neuropsychopharmacol Biol Psychiatry. 2008;32(6):1362- 74.

34. Dell'osso B, Mundo E, Marazziti D, Altamura AC. Switching from serotonin reuptake inhibitors to duloxetine in patients with resistant obsessive compulsive disorder: a case series. J Psychopharmacol. 2008;22(2):210-3.

35. Berlin HA, Koran LM, Jenike MA, Shapira NA, Chaplin W, Pallanti S, et al. Double-blind, placebo-controlled trial of topiramate augmentation in treatment-resistant obsessivecompulsive disorder. J Clin Psychiatry. 2011;72(5):716-21.

36. Harvey BH, Scheepers A, Brand L, Stein DJ. Chronic inositol increases striatal $D(2)$ receptors but does not modify dexamphetamine-induced motor behavior. Relevance to obsessivecompulsive disorder. Pharmacol Biochem Behav. 2001;68(2):245-53.

37. Pallanti S, Bernardi S, Antonini S, Singh N, Hollander E. Ondansetron augmentation in treatment-resistant obsessive-compulsive disorder: a preliminary, single- blind, prospective study. CNS Drugs. 2009;23(12):1047- 55.

38. Amiaz R, Fostick L, Gershon A, Zohar J. Naltrexone augmentation in OCD: a double-blind placebo-controlled cross-over study. Eur Neuropsychopharmacol. 2008;18(6):455-61.

39. Miguel E.C.; Gentil V.; Gattaz W.F. et al .Clinica psiquiatrica - a visão do departamento e do instituto de psiquaitria do HCFMUSP. 2011.

40. Carvalho A.F; Nardi A.E.; Quevedo J. et al. Transtornos psiquiátricos resistentes ao tratamento. Diagnóstico e Manejo. 2015. 